\title{
LA BOTÁNICA
}

Paracelso llevaba una flor en cada mano:

una, amarga y concreta, le enseñó

la mezcla de lo exacto que embellece

la ciencia en los manuales.

Improbable, la otra

le tentaba la sien más distraída

dibujándole pozos sin final

alli donde las brújulas se pierden.

Su sabor, imagino, era más dulce.

Botánica secreta,

igual que a Paracelso

permiteme espiarte las raíces,

que tu tallo al hervir se transparente

aunque sea un instante y luego sigas

creciendo por la tierra alborotada,

impregnando la atmósfera agridulce,

enloqueciendo cada microscopio.

\section{Andrés Neuman}

Disponível em:

<http://www.viep.buap.mx/recursos/documentos/dgdc-spinor-013.pdf> 